\title{
New from Orbis
}

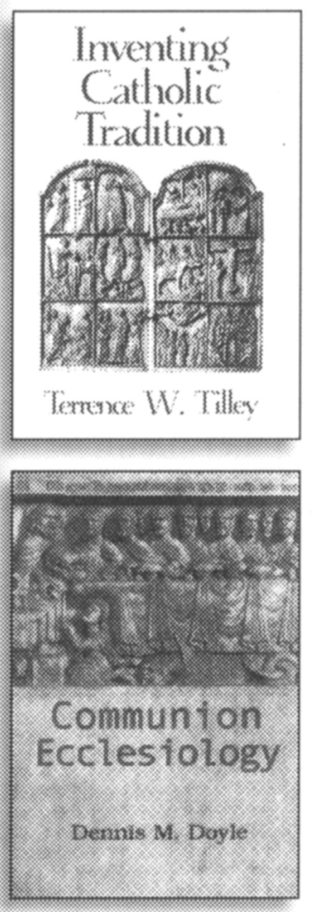

Terrence W.Tilley

Inventing Cathourc Tradition

What Catholic tradition is, how it functions, and how it is lived. Tilley examines the actual practices of tradition and shows how truth, revelation, and authority can be accommodated by a constructive, practical theology of tradition.

"This honest, creative yet faithful treatment could hardly be more timely..."

-SUSAN Ross, Loyola University, Chicago

1-57075-340-7 paper $\$ 24.00$

Dennis M. Doyle

\section{COMMUNION ECClesiologY}

\section{Vision and Versions}

Examines the approaches of Möhler, Journet, Lubac, Congar, Rahner, von Balthasar, Johnson, Ratzinger and many others. "A valuable contribution..."

-Michael J. Himes, Boston College 1-57075-327-X paper $\$ 24.00$
Daniel L. Smith-Christopher, editor

SUbVERTING Hatred

The Challenge of Nonviolence in Religious Traditions

Faith Meets Faith Series

1-57075-323-7 paper $\$ 15.00$

Donal Dorr

\section{MISSION IN}

\section{TODAY'S WORLD}

Presents the opportunities for meeting the 'new frontiers' in mission today.

1-57075-339-3 paper $\$ \mathbf{2 0 . 0 0}$

30 Years of Books that Matter
Walter J. Burghardt

LONG Have I Loved You A Theologian Reflects on His Cburch

"A rich tapestry of our church and our times."

-PAUL WILKES

1-57075-296-6 paper $\$ 20.00$

Robert McClory

Fatthful Dissenters

Stories of Men and Women Who

Loved and Changed the Church

1-57075-322-9 paper $\$ 16.00$

At your bookseller or direct

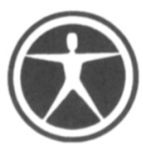

ORBIS BOOKS

Maryknoll, NY 10545

1-800-258-5838

www.orbisbooks.com 


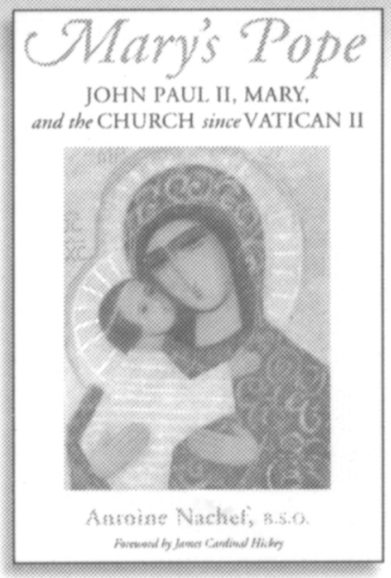

ANTOINE NACHEF

Mary's Pope

John Paul II, Mary, and the

Church Since Vatican II

Foreword by James Cardinal Hickey

"An invaluable resource for those who would know our Blessed Mother and Her Divine Son through the heart and mind of Pope John Paul II."

\section{- John Cardinal O'Connor}

"A rich collection with clear and carefully written commentaries drawn from an abundance of sources."

-William Cardinal Keeler 1-58051-077-9 paperback, 277 pp \$23.95

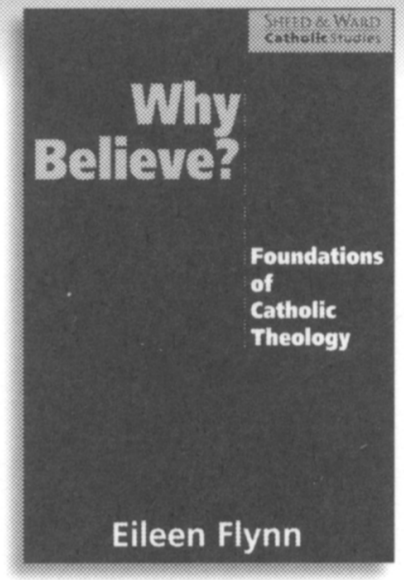

- NEW Catholic Studies Series.

\section{EILEEN FLYNN Why Believe?}

\section{Foundations of Catholic} Theology

"Cogent, succinct, and insightful. By keeping the questions and hopes of the students in focus, Flynn demonstrates that it is possible to stir the hearts of students...this work is simply splendid." -Gloria Durka, Ph.D. Fordham University

"Clear and engaging ... She presents the themes of theology with a view toward their relevance to life today." -Dennis Tamburello, o.F.M. Sienna College 1-58051-083-3 paperback, 258 pp $\$ 24.95$ 


\title{
CONNECTIONS
}

\author{
Linda M. Maloney, Series Editor
}

How does the Word, written so long ago, fit into everyday life today? The Connections series offers today's readers and students of Scripture an answer to that puzzling question.

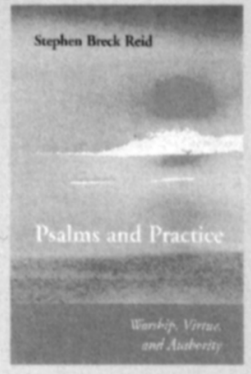

NEW!

PSALMS AND PRACTICE

Worship, Virtue, and Authority Stephen Breck Reid, Editor Practice, according to the authors of Psalms and Practice, is when faith seeks understanding through spiritual disciplines. These essays explore how the notion of practice helps contemporary readers understand psalms in a new way. 0-8146-5080-5 Paper, 296 pp., $6 \times 9, \$ 19.95$
ISHMAEL INSTRUCTS ISAAC

An Introduction to the Qur'an for Bible Readers John Kaltner

"Reading it may help us work toward family reconciliation born of a mutual respect and understanding."-Kathleen M. O'Connor,

Columbia Theological Seminary

0-8146-5882-2 Paper, 312 pp., 6 x 9, \$24.95

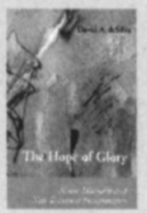

\section{THE HOPE OF GLORY}

Honor Discourse and

New Testament Interpretation David A. deSilva

"... a compelling grasp of how early

Christianity thrived in the midst of a hostile social environment. .."-Robert Jewett, Garrett-Evangelical Theological Seminary

0-8146-5823-7 Paper, 248 pp., 6 x 9, \$22.95

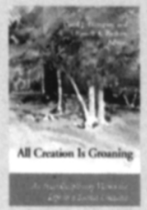

\section{ALL CREATION IS GROANING}

An Interdisciplinary Vision

for Life in a Sacred Universe

Carol J. Dempsey and Russell A. Butkus, Editors and Weavers; foreword by Walter Brueggemann "... a magnificent resource..."

-Denis Edwards, Flinders University

0-8146-5932-2 Paper, 336 pp., 6 x 9, \$27.95

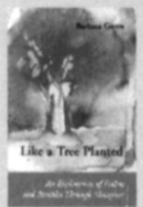

\section{LIKE A TREE PLANTED}

An Exploration of the Psalms and Parables Through Metaphor Barbara Green, O.P.

"Green's book occupies territory somewhere between the work of Phyllis Trible and -

Barbara Brown Taylor, a high commendation indeed!"

-Walter Brueggemann, Columbia Theological Seminary

0-8146-5869-5 Paper, 160 pp., 6 x 9, \$14.95

For more information, see www.catalog.litpress.org/series_list.cfm?ID=29

\section{CALL FOR A FREE BROCHURE.}

Shipping is additional. Available from your religious bookstore or

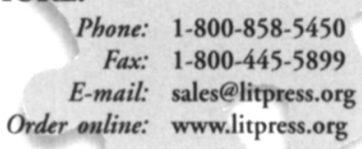

